\title{
INSR wt Allele
}

National Cancer Institute

\section{Source}

National Cancer Institute. INSR wt Allele. NCI Thesaurus. Code C52170.

Human INSR wild-type allele is located within 19p13.3-p13.2 and is approximately $177 \mathrm{~kb}$ in length. This allele, which encodes insulin receptor protein, plays a role in the regulation of glucose uptake. Mutations in either the structural gene or processing steps may lead to insulin resistance. 